\title{
Learning medical ethics with our new neighbours
}

\author{
John Saunders
}

\author{
Postgraduate Organiser, North Gwent; Nevill Hall Hospital, Abergavenny, Gwent, NP7 7EG and Centre \\ for Philosophy \& Health Care, University College, Swansea, UK
}

The revolutions of 1989 remind us that Europe is more than the nations of the European Community, NATO or EFTA. New European states have been born; the concept of central Europe - the old Mitteleuropa - has re-emerged. Relative economic backwardness colours our view: we establish 'know-how' funds or send in advisors or discuss aid. We should also ask what our new neighbours can teach us.

The European Travelling Fellowship of the National Association of Clinical Tutors gave me an exciting opportunity in 1992 to see medicine - and more specifically medical ethics - from a different perspective in Moravia, Bohemia and Poland. We have much to gain from the mutual exchange of ideas.

Both the Czech Republic and Poland are undergoing major reforms in their health care. ${ }^{1-4}$ These involve problems common to all industrialized countries: the place of technology, changing professional roles, rising demands, new educational needs, an aging population. Medical ethics is further coloured by its emergence from a domineering Marxist philosophy and a distinct historical experience. These differ in Poland and the Czech Republic. Communism had greater popular support in post-war Czechoslovakia, but became more repressive, especially after 1968. The Roman Catholic Church has played a bigger role in medical ethics in Poland, contrasting with the dissenting tradition in Czech religious life. I have discussed aspects of medical ethics in Poland elsewhere ${ }^{5}$ and confine these comments to the Czech Republic.

Although indefensible paternalism is far from dead in British medicine, the hierarchical structure of communist society encouraged an even greater acceptance of medical hegemony. 'It's an unwritten law,' said a biochemist in Jindruchuv Hradec, near Bohemia's southern border, 'the doctor isn't allowed to tell the patient the diagnosis.' The response was to be a familiar one. A physician in

Correspondence: J. Saunders, M.A., M.D., F.R.C.P.

Dr Saunders received the 1992 National Association of Clinical Tutors European Travelling Fellowship.

Accepted: 17 May 1993
Olomouc would not confirm malignancy to $\mathrm{a} \stackrel{\vec{\circ}}{-}$ patient even with a scan showing liver metastases, a $\vec{\omega}$ lung full of cannonball shadows and a fully com- $-\frac{\Omega}{\circ}$ patible history. In Prague I was told that $99 \%$ ofo patients were 'not strong enough' for a terminal: diagnosis; and anyway it would create problems for 8 doctors if patients had too much information. On a ward round in another Prague hospital, I was told. that a hemiplegic, aphasic, unresponsive 93 -year- $\stackrel{\infty}{\rightarrow}$ old woman would be subjected to cardiopul- 0 monary resuscitation in the event of cardiac arrest. Apart from its futility, I could not help reflecting on $\overrightarrow{ }$ the effect of the attempt on the six other patients in the uncurtained ward area, with beds barely a응 metre apart. Patients were not asked and families $\stackrel{\mathbb{Q}}{-}$ never expressed a view. Things were changing bôt $\overrightarrow{0}$ "you must understand that there is much less interest in these intellectual questions than Britain,' said a prominent physician. Lecturing Pocatky on National Health Service changes, the greatest source of interest was the Access to Medical Records Act. Right of access by patients to $\frac{\not}{\mathbb{Q}}$ their case notes was thought radical, even daring $\cong$ legislation.

Against this old-fashioned paternalism, I found articulate and progressive views. 'The most important ethical challenge,' said a leading paediatrician, 'is in relating to parents and in educating them in $\frac{\partial}{3}$ their role in this.' The venerable and distinguished Professor P. Lukl of Olomouc, now in his eighties, wrote recently:

'Truth is valuable in itself and a civilised society is in reality founded on mutual trust and confidence. Lies, even innocent lies, humiliate the deceived and corrupt the character of the liar, turning him or her cynical towards the truth and moral principle . . . Patients have the right to expect the doctor to be honest and to tell them, at the right time, the inevitable truth . . ${ }^{96}$

The Czech Republic's former Health Minister, Martin Bojar, and the Rector of Prague's Charles $\stackrel{\odot}{\hookrightarrow}$ University, Radim Palous, have both encouraged the development of structures where medico-moral $\frac{0}{0}$ issues may be discussed. In this, they are reviving a $\overrightarrow{\mathbb{D}}$ dormant tradition. Compared with Britain, 
philosophy had a bigger role in middle class - and hence doctors' - education, pre-war and earlier. An Institute of Deontology was established in 1946, long before the UK's Institute of Medical Ethics. In 1990, the Scientific Council of the Czech Ministry of Health created a Central Ethical Committee.? The committee elaborates opinions and recommendations for the Ministry and for legislative bodies in matters of medical ethics. Although medically dominated it also includes two deputies from the Czech parliament, and protestant and roman catholic theologians. I was privileged to attend one of its meetings - an impressive openness by British standards with their secrecy and status. The issues under discussion had immediacy and relevance. Was it ethical for doctors to strike? (Everyone knows a doctor earning 20 times the salary in Britain or Germany.) Was psychiatry used for social control or as a political weapon? New medical technologies (for example, reproductive technologies) are also considered but perhaps there is something for us to learn in a national body actively debating the ethics of everyday issues. The committee certainly conducted its debate vigourously.

In Brno, Olomouc and in all three medical faculties in Prague, undergraduate teaching programs in medical ethics have been developed. Curriculum time has come from the former compulsory lectures on Marxism. At Prague's 3rd Medical Faculty, an Institute of Medical Ethics was founded in 1990, with staff backgrounds in sociology, psychology, philosophy and medicine. The curriculum includes an overview of philosophy. The possibility of meeting the names of Hegel or Heidigger would, I think, daunt all but the most catholic minds here. Much will be optional but there will be compulsory lectures in the first year. It will also be tested - an indication that the subject is being taken seriously. In the 1st Faculty, an institute for medical humanities has been created by incorporating academics in sociology and public health. It was acknowledged that few medical students are interested in philosophy: medical ethics must be relevant to daily human concerns. A first year included one semester of general ethics, then some philosophical anthropology, religious sciences and hermeneutics; the second year introduced more medical ethical themes; then medical psychology, psychosomatics and sociology in the 3rd, 4th and 5th years - always implicitly teaching ethics. In Olomouc, Professor Lukl takes an approach grounded in a long lifetime's experience. A series of case studies are presented to students for discussion in seminars. The program in Olomouc begins with an introduction explaining such concepts as utilitarianism, deontology and autonomy. In the second session, truth telling and paternalism are covered; then practical questions of resuscitation and euthanasia in the third. The curriculum thereafter remains grounded in daily concerns with an admirable breadth - homosexuality, family life and alcohol are not topics addressed in most standard British accounts of medical ethics.

Although such teaching programmes seem ahead of many in Britain, not all students were convinced of their value. Partly there was a suspicion based on previous ideological indoctrination. One director of studies related how only 15 students out of 120 attended; another instanced six out of 90 . A typical student response, alleged another, was 'I know that's how it should be, but in practice we just do such and such. That's how it is in "real" life.' Perhaps appropriately, undergraduate lectures in Brno begin with a seminar on "why study medical ethics at all?'

Local ethical committees have been established in all university and large regional hospitals. That in Olomouc, for example, has 12 members consisting of 10 medical members, one lawyer and one nurse. Establishing committees has been made urgent by the probability of international pharmaceutical companies expanding clinical research activities in the Czech Republic. Good scientific standards, low costs and an eagerness for foreign exchange by the host increase the risk of unethical patient exploitation. The educational need is therefore considerable for postgraduates also. Privatisation was increasing doctors' interest in money at the expense of human concerns, thought one. Many doctors seemed concerned that market reforms were being taken too far - sounding a common note of concern with many in the UK. At the Olga Havel Foundation, an umbrella charitable organization, its director, Dr Hubalek, acknowledged that after 20 years of discussion the former dissidents now had to act. This meant facing the problems of rising prices, poor medical salaries, too many doctors, a drug and equipment market enfeebled by Soviet use of Czechoslovakia as a weapons factory and open to western products at high prices, the need to encourage primary care and to ration technology (there are $30 \mathrm{CT}$ scanners in the Czech Republic). Yet in this climate he thought education in medical ethics was supremely important. Two or three generations had been educated without it, yet ethics related to basic attitudes. Ethics existed to change society and not to reflect it. The contrast between 'having' and 'being' is particularly acute. Here the ethical and philosophical tradition in other western countries could make a valuable contribution. I hope so. His combination of pragmatism and idealism was as humbling as it was inspiring.

Many Czech intellectuals are eager to discuss and to teach ethics in medicine. I gained the impression of a broader view of the subject than 
often found in Britain. Discussion at the highest level is open. Undoubtedly we in Britain have something to offer: the doctor-patient relationship, for example, is more equal and the implications of the concept of autonomy better developed. Czechs also have something to teach us: the nature of man and his place in society, the particulars of their teaching programmes, the different emphases that derive from a different historical experience, their analyses and creative responses to current problems that have so many parallels to our own. Visits like mine reveal minutiae of daily practice that conference meetings miss - the context of ethical debate. Intellectual isolation remains a problem. Geography alone makes links with German medicine easier than with the AngloAmerican tradition - with likely consequences for sales of drugs and equipment. It is possible to visit Austria with fuel purchased at home prices. Similarly, western journals are prohibitively expensive. The launch of a monthly Czech and Slovak

\section{ferences}

1. Albert, A., Bennett, C. \& Bojar, M. Health Care in the Czech Republic. JAMA 1992, 267: 2461-2466.

2. Jaros, J. \& Towell, D. Strange route in health care in Europe: Czechoslovakia. Health Services J 1992, 29 October, 24-27.

3. Drobniewski, F. Health care in the Czech Republic. $J$ R Coll Phys Lond 1992, 26: 393.

4. Chopin, K. Letter from Poland. Br Med J 1992, 304: $1429-1432,1495-1497,1557-1560$. edition of $J A M A$ is one imaginative response, a journal chosen partly because of its breadth. 3 Donated journals or the organization of visits to $\stackrel{\mathbb{Q}}{\propto}$ UK district hospitals to see and discuss the prob- $c$. lems of delivering routine care can, I believe, be $\vec{F}$ enormously valuable - to us and to colleagues in our own intellectual tradition and continent.

\section{Acknowledgements}

I am indebted to Czech colleagues for many kindnesses; especially Rudolf Chlup, Ivo Krc, Helena Hascovcova, $\vec{\circ}$ Jan Herget, Slavomil Hubalek, Jan Janda, Petr Jasek, Jan Payne and Blazena Poudrozkova.

\section{Further information}

The UK branch of the Olga Havel Foundation is at: $104-3$ Elgin Crescent, London W11 2JL (Tel. 071-727-6651; fax 071-727-6513). The Czech Ministry of Health has an $\stackrel{\infty}{-}$ International Cooperation Department at Palackeho nam. 4, 12801 Praha 2.

5. Saunders, J. Polish medical ethics - an outsider's view. Bull Med Ethics 1993, no. 85 (February), 20-22.

6. Lukl, P. Some ethical problems in medicine and cardiolo Eur Heart J 1992, 13: 431-432.

7. Haderka, J. Ethics committees in Czechoslovakia. Bull Mad Ethics 1991, no. 69 (June), 18-19. 